\title{
Prototype Arm Robotic 6 Axis Untuk Menyiapkan Kompetensi Pemrograman Matakuliah Mekatronika Mahasiswa Prodi D3 Teknik Mesin
}

\author{
Marsono $^{1)}$, Ilham Ari Elbaith Zaeni ${ }^{2)}$, Abdul Qolik ${ }^{3)}$ \\ Fakultas Teknik, Universitas Negeri Malang \\ Jalan Semarang 5 Malang \\ e-mail:*1marsono.ft@um.ac.id
}

\begin{abstract}
Abstrak: Seiring dengan pesatnya perkembangan teknologi pada akhir dekade ini, dunia industry mengubah sumber daya yang mereka miliki menggunakan bantuan teknologi robot. Penggunaan robot dipilih karena keakuratan dan kepresisian yang mampu dilakukan dalam melakukan pekerjaan. Selain itu, teknologi robot hanya memerlukan satu kali pemrograman untuk melakukan banyak hal. Dengan demikian banyak keuntungan yang diperoleh perusahaan dengan menggunakan teknologi robot dalam proses produksinya.

Menyikapi kondisi tersebut, dunia pendidikan khususnya Universitas harus segera menyiapkan lulusannya yang memiliki kompetensi sesuai kebutuhan industry dalam pemrograman robot lengan. Program studi D3 Teknik Mesin sebagai salah satu program studi bidang teknik rekayasa sudah memberikan salah satu matakuliah untuk membekali lulusannya yaitu dalam matakuliah mekatronika. Akan tetapi, terdapat kekurangan dibidang sarana dan prasarana yaitu belum adanya lengan robot untuk pembelajarannya. Selama ini, mahasiswa belum diberikan materi ajar pemrograman robot lengan sehingga apabila lulusan bekerja di industry yang menggunakan robot lengan mereka akan mengalami kesulitan.

Penelitian ini adalah penelitian pengembangan dengan merancang dan membangun Prototype Arm Robotic 6 Axis untuk mengajarkan bahasa pemrograman robot lengan. Hasil dari penelitian ini berupa prototype robot lengan dengan pemrograman berbasis Arduino. Harapannya dengan adanya protopype ini mahasiswa akan dapat dengan mudah dan terbiasa memprogram robot lengan khusunya untuk gerakan-gerakan pekerjaan yang sama dengan yang dikerjakan di dunia industry.
\end{abstract}

Kata Kunci: Prototype, Arm Robotic 6 Axis, Pemrograman, Arduino, Teknik Mesin

Seiring dengan pesatnya perkembangan teknologi pada akhir dekade ini, dunia industry mengubah sumber daya yang mereka miliki menggunakan bantuan teknologi robot. Penggunaan robot dipilih karena keakuratan dan kepresisian yang mampu dilakukan dalam melakukan pekerjaan. Selain itu, teknologi robot hanya memerlukan satu kali pemrograman untuk melakukan banyak hal, ditambah robot memiliki banyak kelebihan yang tidak dimiliki manusia, yaitu menghasilkan kualitas yang sama ketika mengerjakan suatu pekerjaan secara berulang-ulang, tidak mudah lelah, dan dapat diprogram ulang sehingga dapat difungsikan untuk beberapa tugas yang berbeda. Dengan demikian banyak keuntungan yang diperoleh perusahaan dengan menggunakan teknologi robot dalam proses produksinya.

Menyikapi kondisi tersebut, dunia pendidikan khususnya Universitas harus segera menyiapkan lulusannya yang memiliki kompetensi sesuai kebutuhan industry dalam pemrograman robot lengan. Program studi D3 Teknik Mesin sebagai salah satu program studi bidang teknik rekayasa sudah memberikan salah satu matakuliah untuk membekali lulusannya yaitu dalam matakuliah mekatronika. Akan tetapi, terdapat kekurangan dibidang sarana dan prasarana yaitu belum adanya lengan robot untuk pembelajarannya. Selama ini, mahasiswa belum diberikan materi ajar pemrograman robot lengan sehingga apabila lulusan bekerja di industry yang menggunakan robot lengan mereka akan mengalami kesulitan.

Penelitian ini adalah penelitian pengembangan dengan merancang dan membangun Prototype Arm Robotic 6 Axis untuk mengajarkan bahasa pemrograman robot lengan. Hasil dari penelitian ini berupa prototype robot lengan dengan pemrograman berbasis Arduino. Harapannya dengan adanya protopype ini mahasiswa akan dapat dengan mudah dan terbiasa memprogram robot lengan khusunya untuk gerakan-gerakan pekerjaan yang sama dengan yang dikerjakan di dunia industry. 


\section{TINJAUAN PUSTAKA}

\subsection{Robot Lengan}

Robot lengan atau yang lebih dikenal dengan Manipulator Robot adalah salah satu jenis robot yang paling banyak digunakan oleh masyarakat industri. Ataupun sering dikatakan sebaliknya sebuah robot manipulator industri umumnya sering disebut sebagai lengan robot, dengan link dan sendi. Manipulator robot yang meniru karakteristik lengan manusia disebutnjuga lengan diartikulasikan. Semua sendi mereka rotary (atau revolute). Walaupun demikian, gerakan diartikulasikan lengan robot berbeda dari gerakan lengan manusia (Bruno \& Oussama, 2008).

Sementara sendi robot memiliki derajat lebih sedikit kebebasan atau disebut derajat kebebasan atau Degree of Freedom (DOF), manipulator robot dapat bergerak bebas walaupun dari suatu sudut tertentu dengan kebebasan yang lebih disbanding manusia (Craig, 1989). Misalnya, siku dari robot diartikulasikan dapat menekuk ke atas atau bawah sedangkan seseorang hanya bisa menekuk siku mereka dalam satu arah selebihnya hanya pada posisi lengan lurus.

Manipulator dikelompokkan ke dalam kelas sesuai dengan kombinasi sendi yang digunakan sesuai dalam konstruksi manipulator robot tersebut. Sebuah lengan geometri Cartesian (kadang-kadang disebut crane gantry) hanya menggunakan prismatik sendi, dan dapat mencapai posisi apapun di ruang kerja persegi panjang yang oleh gerakan Cartesian link. Dengan mengganti sendi pinggang lengan Cartesian dengan bersama revolute, lengan geometri silinder terbentuk (Endra, 2006).

\subsection{Bagian-Bagian Lengan Robot}

Secara keseluruhan sebuah sistem lengan robot manipulator terdiri dari (Muhammad, 2016): 1. Tangan Mekanik (Mechanical arm); 2. End-Effector; 3. Penggerak (Actuator); 4. Sensor/Transducer; 5. Pengendali (Controller).

\subsection{Mikrokontroler Arduino Uno}

Arduino Uno adalah kit elektronik atau papan rangkaian elektronik open source yang di dalamnya terdapat komponen utama yaitu sebuah chip mikrokontroler dengan jenis AVR dari perusahaan Atmel. Arduino adalah sebuah board mikrokontroller yang berbasis ATmega328 (Gastomo, 2018). Arduino memiliki 14 pin input/output yang mana 6 pin dapat digunakan sebagai output PWM, 6 analog input, crystal osilator $16 \mathrm{MHz}$, koneksi USB, jack power, kepala ICSP, dan tombol reset. Arduino mampu men-support mikrokontroller; dapat dikoneksikan dengan komputer menggunakan kabel USB. Pada gambar 1.2 terdapat 14 pin output/input yang mana 6 pin dapat digunakan sebagai output PWM (Pulse Width Modulation), 6 analog input, crystal osilator $16 \mathrm{MHz}$ dan tombol reset. Arduino tersebut digunakan sebagai chip mikrokontroler328, sebagai pengendali gerakan motor DC.

\subsection{Motor Servo}

Motor servo adalah sebuah motor dengan sistem umpan balik tertutup di mana posisi dari motor akan di informasikan kembali ke rangkaian control yang ada di dalam motor servo. Motor ini terdiri dari sebuah motor DC, serangkaian gear, potensiometer dan rangkaian kontrol. Potensiometer berfungsi untuk menentukan batas sudut dari putaran servo. Sedangkan sudut dari sumbu motor servo diatur berdasarkan lebar pulsa yang dikirim melalui kaki sinyal dari kabel motor.

Berikut gambar 1.2 adalah pin-pin pada kit arduino uno yang digunakan pada rancangan alat ini:

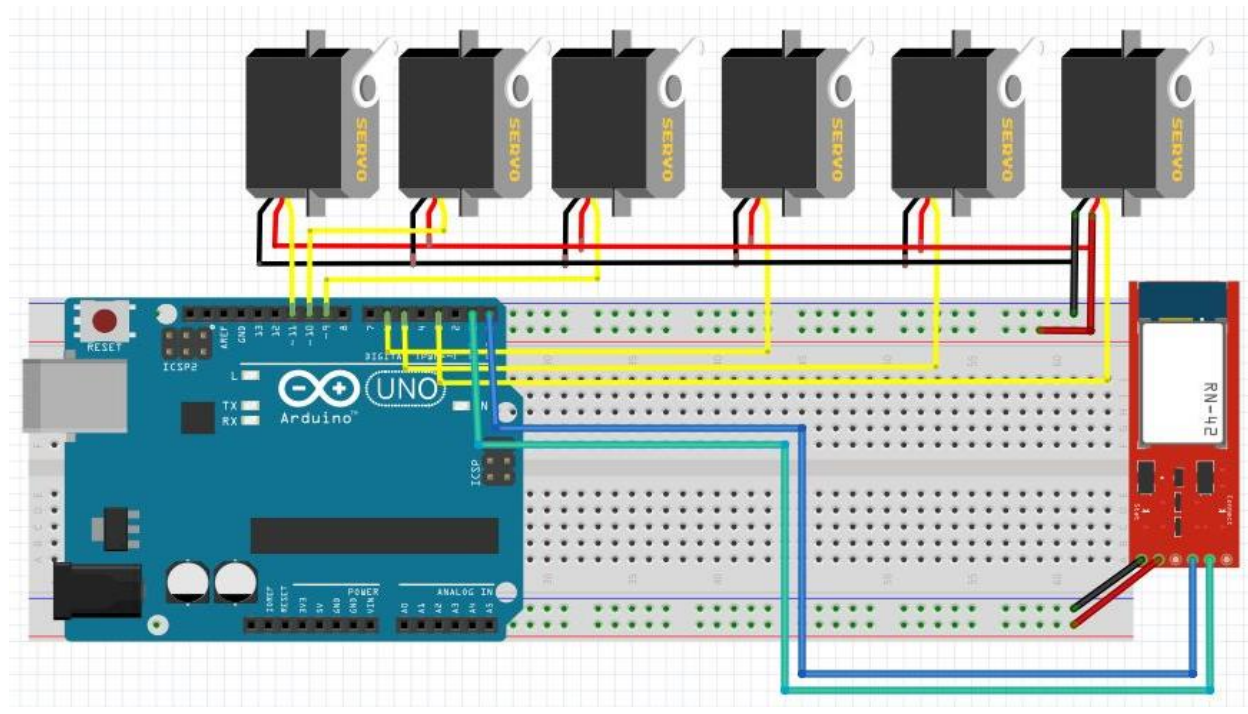

Gambar 1.2 Pemasangan servo pada Arduino 


\section{METODE}

\subsection{Rancangan Penelitian}

Penelitian ini akan dibuat suatu program didalam suatu mikrokontroler untuk mengaplikasikan persamaan kinematic. dengan tahapan penelitian sebagai berikut :

1. Studi Literatur; 2. Perancangan perangkat keras dan lunak; 3. Pemasangan rangkaian listrik dan pembuatan mekanik serta pembuatan program; 4. Pengujian Alat; 5. Analisis dan pembuatan artikel.

\subsection{Perancangan Hardware}

Agar program pada perangkat lunak dapat bekerja perlu dilakukan perancangan perangkat keras untuk mengimplementasikan persamaan kinematic dari perancangan pada perangkat lunak. Selanjutnya untuk feedbacknya adalah data dari sensor pada robot yaitu mini potensiometer yang akan masuk kembali sebagai input untuk proses forward kinematics. Kedua proses ini terdapat dalam Arduino yang berfungsi sebagai pusat pengolahan dan pengiriman data. Data theta dari inverse kinematics akan diolah selanjutnya kedalam program dynamic.

\subsection{Perancangan Software}

Setelah perancangan perangkat keras selesai dilakukan, maka akan dibuat perancangan perangkat lunak atau program. Bahasa visual hanya sebagai interface untuk menampilkan output dan sebagai input pada proses inverse sedangkan semua proses akan diolah dengan mikrokontroler Arduino dan kemudian hasil proses tersebut akan diteruskan menjadi sebuah pergerakan pada motor. Dalam proses ini tidak terdapat kendali close loop dikarenakan kendali close loop telah diproses pada peneliti motor. Disini proses forward dan inverse digunakan sebagai konversi nilai angle maupun end effector.

\subsection{Prosedur Analisis dan Pengambilan Data}

Pengambilan data dan percobaan dilakukan beberapa tahap pengujian yaitu:

1. Pengujian Mekanik: Pada proses ini akan diuji tata letak mekanik lengan robot terhadap letak sebenarnya; 2. Pengujian Pergerakan Robot: Pada proses ini di uji apakah robot telah dapat berjalan dengan baik dan sesuai dengan yang target output yang diinginkan baik end effector ataupun angle; 3. Pengujian Implementasi: Program yang telah dibuat pada Arduino terhadap Mekanik Robot. Pada tahap ini di uji tingkat keberhasilan program yang telah dibuat dan digabungkan dengan aktualisasi mekanik robot; 4. Pengujian tingkat keakurasian posisi lengan robot: Pada tahap ini akan diuji tingkat keberhasilan pergerakan lengan robot mencapai posisi target yang dinginkan dengan membandingkan hasil perhitungan yang diperoleh dari perhitungan kinematik dengan pengukuran menggunakan bidang cartesian $(\mathrm{x}, \mathrm{y}, \mathrm{z})$ pada robot . Dan menampilkan hasil persentase error pada setiap sumbu cartesian $(\mathrm{x}, \mathrm{y}, \mathrm{z})$.

\section{HASIL}

\subsection{Hasil Kinematika Maju dan Balik}

Kinematika dapat didefinisikan sebagai studi pergerakan robot tanpa memperhatikan gaya (force) ataupun faktor lain yang mempengaruhi pergerakan robot tersebut. Pada analisis kinematik, posisi, kecepatan dan akselerasi dari seluruh link dihitung tanpa memperhatikan gaya yang menyebabkan pergerakan tersebut. Kinematika robot secara umum terbagi menjadi dua, yaitu kinematika maju (forward kinematic) dan kinematika balik (inverse kinematic).

Kinematika maju adalah analisis kinematik untuk mendapatkan koordinat posisi (x, y, z) jika diketahui sudut dari tiap sendi. Sebagai contoh, apabila mempunyai robot n-DOF dan diketahui sudut dari tiap sendi maka dapat menggunakan analisis kinematik maju untuk mendapatkan koordinat posisi robot. Kinematika balik adalah analisi kinematik untuk mendapatkan besar sudut dari masing-masing sendi jika diketahui data koordinat posisi (x, y, z) (Rainer, 2016; Rosen, 1989; Serdar \& Zafer, 2006).

\subsection{Analisis Kinematik dengan Persamaan Trigonometri}

Analisis persamaan kinematik dapat diselesaikan dengan cara yang paling dasar, yaitu menggunakan persamaan trigonometri. Setiap komponen dalam koordinat $(\mathrm{x}, \mathrm{y}, \mathrm{z})$ dinyatakan sebagi transformasi dari tiap-tiap komponen ruang sendi (r, $\theta$ ) dimana jari-jari r merupakan panjang lengan atau link.

Forward Kinematik :

Pada analisis forward kinematic, apabila sudut sendi diberi nilai sebesar $\theta$, maka posisi ujung lengan $\mathrm{p}(\mathrm{x}, \mathrm{y})$ dapat diketahui dengan menggunakan Persamaan 3.1 dan 3.2 berikut:

$$
\begin{aligned}
& x=l \cdot \cos \theta \\
& y=l \cdot \sin \theta
\end{aligned}
$$

Inverse Kinematik:

Apabila posisi ujung lengan yang diinginkan adalah $\mathrm{p}(\mathrm{x}, \mathrm{y})$, maka besar nilai sudut $\theta$ dapat dihitung dengan menggunakan Persamaan 3.3 berikut: 


$$
\theta=\tan ^{-1}\left(\frac{y}{x}\right)
$$

(Suwarno, 2008)

\section{Pemrograman Robot Lengan}

Pada praktikum kontroler robot lengan menggunakan Arduino Mega 2560 dengan standar bahasa $\mathrm{C}$ yang dapat langsung dicompile dengan mudah. Sebelum memulai pemrograman robot lengan, terlebih dahulu harus diketahui beberapa variabel yang ada pada robot lengan, seperti jumlah DOF, panjang masing-masing link, dan sudut kerja motor servo yang digunakan. Sebagai contoh desain robot lengan yang digunakan pada praktikum ini adalah seperti Gambar 4.8 berikut.

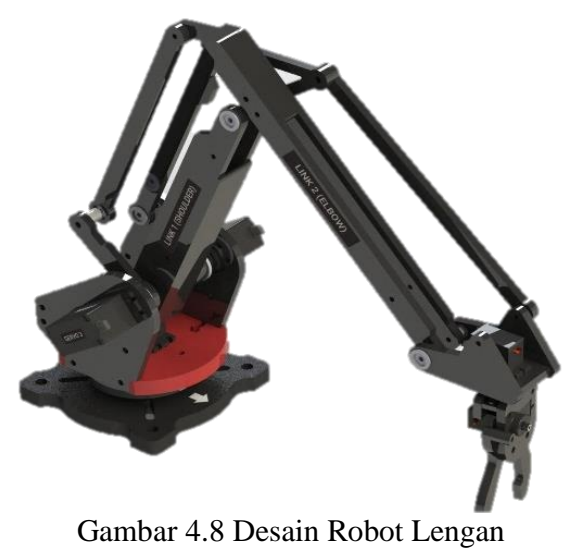

Pada desain ini robot lengan terdiri dari 2 link dan 5 sendi. Link 1 (Shoulder) memiliki panjang 148 mm dan link 2 (elbow) memiliki panjang $160 \mathrm{~mm}$.

\subsection{Kesimpulan}

\section{KESIMPULAN DAN SARAN}

Prototype arm robot 6 axis ini dibuat untuk memberikan mahasiswa kompetensi pemrograman pada matakuliah mekatronika. Dalam perancangan dan pembuatannya terdapat beberapa kendalan, diantaranya mencari komponen elektronika dan pembuatan module penghubung servo ke Arduino. Perlu perhitungan pulsa yang cermat sehingga dapat diperoleh perubahan arah pergerakan lengan robot yang diinginkan. Pergerakan lengan robot masih belum smooth/halus karena masih menggunakan motor servo, sehingga masih perlu pengembangan lebih lanjut untuk mendapatkan perpindahan gerakan yang halus.

\subsection{Saran}

Dengan sangat pesatnya perkembangan penggunaan robot di dunia industri, maka matakuliah mekatronika khususnya untuk prodi D3 teknik Mesin harus segera diarahkan pada pemrograman robotic. selain itu, tugas akhir mahasiswa harus diarahkan pada pengembangan-pengembangan penerapan robot di kehidupan sehari-hari. Motor jenis steper sangat dianjurkan untuk pengembangan robot lengan berikutnya untuk memperhalus arah perubahan gerakan.

\section{DAFTAR PUSTAKA}

Bruno, S \& Oussama, K. 2008. Handbook of Robotics. Springer Science \& Business Media, 2008. pp. 9-31.

Endra, P. 2006. Disain, control, dan Kecerdasan Buatan XE "Kecerdasan, buatan". Yogyakarta: Andi Yogyakarta.

Gastomo. 2018. Arduino Uno, http://www.academia.edu/14708355/Arduino_Uno.

Muhammad, F.F. 2016. Perancangan Arm Manipulator 4 DOF dengan Menggunakan Pengendalian Cartesian Space Line Trajectory Planning, Universitas Diponegoro, Semarang.

Rainer, H. 2016.Kinematics for Lynxmotion Robot Arm. http://www.hessmer. Org / uploads / Robot Arm / Inverse \% 2520 Kinematics \% 2520 for \% 2520 Robot\%2520Arm. pdf

Rosen, J. 1989. Model of Robot XE "Robot" Manipulation : Introduction \& Basic Ideas - Speed Description \& Transformation. Washinton: Department of Electrical Engineering -University of Washinton.

Suwarno. 2008. Analisis Kinematika Mobile Manipulator Pada Robot Penjinak Bom. Tesis. Makassar: Universitas Hasanuddin. 